ROCZNIK ADMINISTRACJI PUBLICZNEJ 2021 (7)

ARTYKULY / ARTICLES

Administracyjne prawo proceduralne

Administrative Procedural Law

StanISLAW BIERnAT ${ }^{1}$

\title{
Czego uczą pytania prejudycjalne sądów administracyjnych
}

\section{Wprowadzenie}

Pytania prejudycjalne są wdzięcznym przedmiotem badań, z co najmniej dwóch względów. Po pierwsze, jest to jak wiadomo, podstawowa forma współpracy sądów krajowych z Trybunałem Sprawiedliwości Unii Europejskiej (TSUE) i instrument zapewnienia jednolitego oraz prawidłowego stosowania prawa unijnego w państwach członkowskich. Po drugie, na stronie internetowej NSA znajduje się zakładka, w której zamieszczone są linki do wszystkich postanowień sądów administracyjnych o skierowaniu pytań prejudycjalnych, opinie rzeczników generalnych (jeśli zostały sporządzone) oraz orzeczenia TSUE w odpowiedzi na pytania ${ }^{2}$. Dane zawarte $w$ tej zakładce pozwalają na śledzenie dotychczasowych doświadczeń w dziedzinie dialogu polskich sądów administracyjnych z TSUE. Początkowo były tam także zamieszczane linki do orzeczeń sądów administracyjnych wydanych po otrzymaniu odpowiedzi z Luksemburgu. Od tego niestety później odstąpiono. $Z$ zawartości omawianej zakładki autor tych słów korzysta zawsze $\mathrm{z}$ sentymentem, ponieważ została ona utworzona w 2006 r., w czasie kiedy był naczelnikiem Wydziału Prawa Europejskiego w Biurze Orzecznictwa NSA.

Warto zacząć od przytoczenia kilku podstawowych informacji statystycznych.

Jak wynika z corocznych sprawozdań TSUE, od początku członkostwa Polski w Unii Europejskiej w 2004 r., do końca 2020 r. polskie sądy wystąpiły do TSUE w sumie z 238 odesłaniami prejudycjalnymi ${ }^{3}$. W tej liczbie

1 Prof. dr hab. Stanisław Biernat, Katedra Prawa Europejskiego, Uniwersytet Jagielloński.

2 https://www.nsa.gov.pl/pytania-prejudycjalne-wsa-i-nsa.php.

3 Chodzi tu o liczbę postanowień odsyłających polskich sądów, w których może być jedno lub wiele pytań. 
mieści się 87 odesłań skierowanych przez sądy administracyjne, co stanowi $36,5 \%$. Dokładnie dwie trzecie odesłań pochodziło od NSA, a jedna trzecia od poszczególnych WSA. Najbardziej aktywny był sąd we Wrocławiu, który zwrócił się do TSUE osiem razy.

Dość klarownie przedstawia się obraz tematyki pytań prejudycjalnych kierowanych przez sądy administracyjne. Znaczna ich większość, bo aż 70 dotyczy spraw podatkowych. Odnoszą się one głównie do interpretacji dyrektywy Rady 2006/112 z 28 listopada 2006 r. w sprawie wspólnego systemu podatku od wartości dodanej (VAT)4. Pytania sądów i odpowiedzi TSUE w sprawach podatkowych są niewątpliwie istotne dla praktyki administracyjnej i sądowej. Jak się jednak wydaje, wnoszą one mniej do rozwoju prawa unijnego i ogólnie prawa polskiego ${ }^{5}$. $Z$ tego względu zostaną pominięte w dalszych rozważaniach ${ }^{6}$.

Przedmiotem poniższej analizy będzie przedstawienie „W pigułce” sześciu wybranych, różnorodnych odesłań prejudycjalnych sądów administracyjnych i wyroków TSUE wydanych w odpowiedzi na nie. Ściślej rzecz biorąc, omawianych tu odesłań jest więcej, ale w niektórych przypadkach TSUE połączył sprawy do wspólnego rozpoznania ${ }^{7}$. W innych przypadkach z kolei, niektóre sprawy zostały połączone do łącznego omówienia w niniejszym opracowaniu ze względu na ich podobieństwa treściowe.

Dokonany wybór spraw jest subiektywny. Decydujące było to, czy w pytaniach sądów administracyjnych, albo w wyrokach TSUE można znaleźć ciekawe zagadnienia albo rozstrzygnięcia istotne $\mathrm{z}$ perspektywy prawa unijnego lub prawa polskiego, czyli takie, z których można wyciągnąć ogólniejsze wnioski i wskazówki na przyszłość.

\section{Odwołania od uchwał Krajowej Rady Sądownictwa (KRS)}

Naczelny Sąd Administracyjny wystąpił w roku 2018 i 2019 z pytaniami prejudycjalnymi ${ }^{8} \mathrm{w}$ związku z rozpoznawaniem odwołań od uchwał KRS (działającej już w nowym składzie) w sprawie przedstawienia Prezydentowi

4 Dz. Urz. L 347 z 11.12.2006, s. 1-118 ze zm.

5 Warto jednak odnotować wyrok TSUE z 29.09.2015 r. C-276/14 Gmina Wrocław przeciw Ministrowi Finansów, którego teza brzmi: „Art. 9 ust. 1 dyrektywy Rady 2006/112/WE z 2006 r. w sprawie wspólnego systemu podatku od wartości dodanej należy interpretować $\mathrm{w}$ ten sposób, że podmioty prawa publicznego, takie jak gminne jednostki budżetowe będące przedmiotem postępowania głównego, nie mogą być uznane za podatników podatku od wartości dodanej, ponieważ nie spełniają kryterium samodzielności przewidzianego w tym przepisie".

6 Poniżej zostanie jednak poddany analizie wyrok TSUE w sprawie C-314/08, Filipiak z dziedziny prawa podatkowego, w którym szczególne znaczenie miały inne zagadnienia.

7 Tak było w omawianym niżej wyroku TSUE w połączonych sprawach C-213/11, C-214/11 i C-217/11, Fortuna.

8 Postanowienia NSA z 21 listopada 2018 r. i 26 czerwca 2019 r. sygn. II GOK 2/18. 
kandydatów na sędziów Sądu Najwyższego (SN). Odwołania te, były wnoszone przez pominiętych kandydatów. NSA postanowił w trakcie postępowania odwoławczego o wstrzymaniu wykonania zaskarżonych uchwał KRS. Nie zważając na to, Prezydent powołał jednak do SN kandydatów wskazanych przez KRS. Rzecz się jednak na tym nie skończyła. Później, Trybunał Konstytucyjny (TK) wydał wyrok ${ }^{9}$, w którym orzekł o niezgodności z Konstytucją art. 44 ust. 1a ustawy o KRS. Przepis ten przyznawał NSA kompetencje do rozpatrywania odwołań od uchwał w sprawach indywidualnych dotyczących powołania do pełnienia urzędu na stanowisku sędziego SN. Następstwem wyroku TK była zmiana ustawy o KRS. Polegała ona na wyłączeniu w ogóle kontroli sądowej w procedurze powoływania sędziów $\mathrm{SN}^{10}$. Ponadto znowelizowana ustawa stanowiła, że postępowania w sprawach odwołań od uchwał KRS w sprawach indywidualnych dotyczących powołania do pełnienia urzędu na stanowisku sędziego SN, wszczęte i niezakończone podlegają umorzeniu z mocy prawa. NSA nie wycofał jednak pytań prejudycjalnych skierowanych wcześniej do TSUE.

NSA wnosił do TSUE o dokonanie interpretacji na tle polskiego prawa art. 19 ust. 1 akapit 2 TUE (zasada skutecznej ochrony sądowej praw jednostek wywodzonych z prawa UE) i art. 267 TFUE (kompetencja sądów krajowych do inicjowania procedury prejudycjalnej).

W wydanym 2 marca 2021 r. wyroku ${ }^{11}$, TSUE wskazał szczegółowo wymagania, jakie wynikają w świetle prawa unijnego dla oceny przepisów normujących status KRS i procedury odwołań od jego uchwał. Zdaniem TSUE, art. 267 TFUE sprzeciwia się stosowaniu przepisów krajowych, które uniemożliwiają NSA korzystanie z procedury prejudycjalnej. Z kolei art. 19 ust. 1 ak. 2 TUE, sprzeciwia się stosowaniu przewidzianej przez prawo polskie nierzetelnej procedury odwoławczej, opisanej dokładnie w wyroku TSUE, (dopóki jeszcze procedura odwoławcza w ogóle była przewidziana).

TSUE stwierdził, że ostateczne rozstrzygnięcie sprawy odwołań od uchwał KRS ma należeć jednak do sądu odsyłającego, czyli do NSA. Sąd ten został zobowiązany do oceny polskich przepisów w świetle prawa unijnego według wskazówek TSUE. W razie niedającej się usunąć niezgodności przepisów krajowych z prawem UE, sąd odsyłający został zobowiązany do odmowy zastosowania tych przepisów, stosownie do zasady pierwszeństwa prawa UE nad całym prawem państwa członkowskiego, łącznie z konstytucją. Rozstrzygnięcie sprawy powinno zostać oparte w takim przypadku na przepisach prawa krajowego, które obowiązywały wcześniej, czyli przed ustanowieniem przepisów uznanych za niezgodne $\mathrm{z}$ prawem unijnym. NSA powinien przy tym ocenić, czy osoby powołane do SN na podstawie

9 Wyrok TK z 25 marca 2019 r. w sprawie K 12/18.

10 Ustawa z dnia 26 kwietnia 2019 r. o zmianie ustawy o Krajowej Radzie Sądownictwa oraz ustawy - Prawo o ustroju sądów administracyjnych, Dz. U. 2019 poz. 914.

11 Wyrok TSUE z dnia 2 marca 2021 r., C-824/18, A.B. przeciwko Krajowej Radzie Sądownictwa, ECLI:EU:C:2021:153 
uchwały organu, mającego takie cechy jak KRS, mogą być w przekonaniu jednostek podatne na wpływy czynników zewnętrznych, a zwłaszcza władzy ustawodawczej i wykonawczej, oraz czy mogą pojawić się wątpliwości, co do ich niezawisłości i bezstronności.

Po otrzymaniu odpowiedzi od TSUE, NSA wydał 6 maja 2021 r., wyrok kończący postępowanie ${ }^{12}$. W wyroku tym, NSA uchylił zaskarżoną uchwałę KRS w całości w punkcie I, tj. w odniesieniu do przedstawienia Prezydentowi RP wniosku o powołanie kilku kandydatów do pełnienia urzędu na stanowisku sędziego SN oraz w punkcie II tj. w odniesieniu do nieprzedstawienia wniosku o powołanie do pełnienia tego urzędu pozostałych kandydatur, w stosunku do skarżącego (AB).

Uzasadnienie wyroku NSA jest obszerne i wielowątkowe, wobec czego, w tym miejscu niektóre kwestie mogą być jedynie zasygnalizowane. Sąd poddał analizie wiele zagadnień $\mathrm{z}$ zakresu prawa polskiego i prawa unijnego, dotyczących zwłaszcza prawa do sądu, efektywnej ochrony prawnej i pierwszeństwa prawa unijnego. NSA szeroko uzasadnił tezę, że obecna KRS nie daje wystarczających gwarancji niezależności od organów władzy ustawodawczej oraz władzy wykonawczej w procedurze powoływania sędziów. NSA uznał za nieuprawnione w świetle Konstytucji i prawa unijnego pozbawienie go kompetencji do rozpoznawania odwołań od uchwał KRS $\mathrm{w}$ procedurze powoływania sędziów SN. Zdaniem NSA, jego kognicja nie ustała w rozpoznawanej sprawie, a w konsekwencji, sąd ten nie jest pozbawiony prawa do przeprowadzenia kontroli zgodności z prawem zaskarżonej uchwały KRS. NSA pominął przy orzekaniu normy wyłączające odwołanie do sądu w omawianej procedurze, wynikające z wspomnianego wyżej wyroku TK i noweli do ustawy o KRS.

NSA stwierdził, że w obecnym stanie prawnym nie przysługuje żaden środek prawny w omawianych sprawach, a obowiązujące poprzednio przepisy dotyczące wnoszenia odwołań od uchwał KRS w procedurze przedstawiania kandydatur na stanowiska sędziów SN, nie spełniały wymagań sprawiedliwości proceduralnej i stwarzały jedynie iluzję środka prawnego. NSA stwierdził, że w sprawie należy zastosować jeszcze wcześniejsze, uchylone już przepisy ustawowe, które odpowiadały standardom prawa unijnego. Tak więc, podstawą rozpoznania odwołania wniesionego w rozpatrywanej sprawie na zaskarżoną uchwałę KRS powinny być przepisy ustawy o KRS w zakresie, w jakim odsyłały do stosowania w postępowaniach w sprawach z odwołań od uchwał KRS przepisów k.p.c. o skardze kasacyjnej.

NSA oceniając w świetle tych przepisów zarzuty zawarte w odwołaniu od uchwały KRS, uznał je za uzasadnione, wobec czego uchylił uchwałę KRS we wskazanym w sentencji zakresie. Równocześnie jednak stwierdził, że skutki wydanego orzeczenia nie odnoszą się do ustrojowej ważności oraz skuteczności prezydenckich aktów powołań na urząd sędziego

12 Wyrok NSA, II GOK 2/18. 
SN dokonanych na podstawie rekomendacji przedstawionych przez KRS w kontrolowanej uchwale.

Omawianą tu sprawę należy uznać za najdonioślejszą spośród tych, w których polskie sądy administracyjne skorzystały z odesłań prejudycjalnych do TSUE. Pytania w tej sprawie, wyrok TSUE wydany w odpowiedzi na nie, i wreszcie wyrok końcowy sądu odsyłającego dotyczą podstawowych i wrażliwych zagadnień dotyczących Polski jako państwa prawa i równocześnie państwa członkowskiego UE. W państwie tym powinny być przestrzegane unijne zasady odnoszące się do niezależności sądownictwa, niezawisłości sędziów i stosowania procedur, które powinny zapewniać skuteczną ochronę prawną. Wyrok NSA został oparty na wskazówkach TSUE, w których zostały powtórzone i skonkretyzowane wymagania wynikające z zasady pierwszeństwa prawa unijnego wobec prawa krajowego. Zasada ta wymaga odmowy zastosowania prawa krajowego, w razie niedającej się usunąć jego niezgodności z prawem unijnym. Tak też było w omawianej powyżej sprawie. NSA odmówił zastosowania przepisów wyłączających sądową kontrolę uchwał KRS, a także przepisów wcześniejszych, które przewidywały procedurę odwoławczą, ale tak skonstruowaną, że nie dawała szans na sprawiedliwe rozpoznanie sprawy. W rezultacie, NSA oparł się na jeszcze wcześniejszych przepisach ustawowych, już uchylonych. Takie rozwiązanie, polegające na „odżyciu” dawnych przepisów, zostało zasugerowane przez TSUE. Jest to konstrukcja znana także z orzecznictwa polskiego Trybunału Konstytucyjnego sprzed 2017 roku.

Uchylenie przez NSA uchwał KRS w omawianym wyroku będzie mieć znaczenie symboliczne. Trudno liczyć na to, że KRS, nie dająca zresztą zdaniem NSA wystarczających gwarancji niezależności od organów władzy politycznej, przeprowadzi ponownie procedurę wyłaniania kandydatów na sędziów SN. Jest tak, tym bardziej, że jak stwierdził NSA na końcu uzasadnienia wyroku - powołanie sędziów do NSA przez Prezydenta zostało nienaruszone.

Dla pełnego obrazu należy dodać, że Trybunał Konstytucyjny wydał 7 października 2021 r. wyrok w sprawie K 3/21, orzekając o niezgodności z Konstytucją przepisów art. 1 akapit 1 i 2 w związku z art. 4 ust. 3, a także art. 19 ust. 1 akapit 2 TUE. W istocie, intencją TK był zamiar pozbawienia skutków prawnych w Polsce niektórych wyroków TSUE, w tym zwłaszcza omówionego wyżej wyroku TSUE z dnia 2 marca 2021 r., jak również uniemożliwienia wydawania przez sądy polskie wyroków, takich jak powołany wyrok NSA z 6 maja 2021 r. Przytoczony wyrok TK spotkał się z krytyką, w której wskazuje się, że został wydany z przekroczeniem kompetencji TK zarówno w świetle Konstytucji, jak i prawa unijnego ${ }^{13}$.

13 Por. S. Biernat, E. Łętowska: Komentarz do oświadczenia sędziów Trybunału Konstytucyjnego w stanie spoczynku z 10 października $2021 \mathrm{r}$, http://konstytucyjny. $\mathrm{pl} / \mathrm{s}$-biernat-e-letowska-komentarz-do-oswiadczenia-sedziow-trybunalu-konstytucyjnego-w-stanie-spoczynku-z-10-pazdziernika-2021-r/. 


\section{Równe traktowanie podatników i pierwszeństwo prawa unijnego}

(wspólnotowego)

Wojewódzki Sąd Administracyjny w Poznaniu zwrócił się do TSUE w $2008 \mathrm{r}$. z odesłaniem prejudycjalnym zawierającym dwa pytania ${ }^{14}$. Odnosiły się one do różnych zagadnień i miały niejednakowe znaczenie w omawianym tu kontekście.

Pierwsze pytanie, rozbudowane i szeroko uzasadnione przez WSA, dotyczyło tego, czy dopuszczalne było wprowadzenie w ustawie o PIT, przepisów o odliczaniu od podstawy opodatkowania składek na ubezpieczenie społeczne i odliczaniu od podatku składek na ubezpieczenie zdrowotne opłacanych w Polsce, z wyłączeniem jednak możliwości odliczania takich składek, gdy były one opłacane ale nieodliczane w innych państwach członkowskich w związku z prowadzoną działalnością gospodarczą.

Trybunał Sprawiedliwości orzekł w odpowiedzi na powyższe pytanie, że prawo wspólnotowe sprzeciwiało się takiemu różnicowaniu, jakie było przewidziane w ustawie o PIT $^{15}$.

Należy jednak zaznaczyć dodatkową okoliczność o istotnym znaczeniu. Te same przepisy ustawy o PIT zostały bowiem zaskarżone już wcześniej do Trybunału Konstytucyjnego i uznane za niezgodne z Konstytucją $\mathrm{RP}^{16}$. Trybunał Konstytucyjny odroczył przy tym utratę mocy obowiązującej, niekonstytucyjnych przepisów o około jeden rok na podstawie art. 190 ust. 3 Konstytucji. W tej sytuacji WSA zawarł w odesłaniu do TSUE drugie pytanie prejudycjalne: czy zasadę pierwszeństwa prawa wspólnotowego należy interpretować w ten sposób, że wyprzedzają one przepisy krajowe przyjęte $\mathrm{w}$ art. 190 ust. 3 Konstytucji RP w zakresie, w jakim na ich podstawie nastąpiło odroczenie wejścia w życie wyroku TK?

$\mathrm{Na}$ to pytanie TSUE odpowiedział, że zasada pierwszeństwa prawa wspólnotowego zobowiązuje sąd krajowy do stosowania prawa wspólnotowego i do odstąpienia od stosowania sprzecznych z nim przepisów krajowych, niezależnie od wyroku krajowego sądu konstytucyjnego, który odracza utratę mocy obowiązującej tych przepisów, uznanych za niekonstytucyjne.

Należy zauważyć, że drugie pytanie WSA i odpowiedź TSUE na nie, są istotniejsze dla rozwoju prawa unijnego i polskiego porządku prawnego. Omawiany wyrok prejudycjalny należy do grupy orzeczeń dotyczących relacji między prawem UE i prawem krajowym oraz relacji między kontrolą zgodności z prawem unijnym sprawowanej przez TSUE a kontrolą

14 Postanowienie WSA z dnia 30 maja 2008 r., I SA/Po 1756/07.

15 Wyrok TSUE z 19 listopada 2009 r. C-314/08, Filipiak przeciwko Dyrektorowi Izby Skarbowej w Poznaniu, ECLI:EU:C:2009:719.

16 Wyrok TK z 7 listopada 2007 r., K 18/06. 
zgodności z Konstytucją, sprawowaną przez sądy konstytucyjne lub sądy najwyższe ${ }^{17}$.

Według TSUE, wobec obowiązywania zasady pierwszeństwa prawa UE, obowiązkiem sądów krajowych jest zapewnienie skuteczności prawu UE i odstąpienie w razie konieczności od stosowania niezgodnych $\mathrm{z}$ nim przepisów krajowych, bez potrzeby uruchamiania procedury zmierzającej do pozbawienia ich mocy obowiązującej stosownie do prawa krajowego. $\mathrm{W}$ przypadku analizowanym, w świetle omawianego wyroku, chodziło o odstąpienie od respektowania wyroku TK, co do odroczenia utraty mocy obowiązującej niezgodnych z konstytucją przepisów ustawy o PIT.

W uwagach na temat tego wyroku nie akcentowano raczej tego, że zawarte $\mathrm{w}$ wyroku TSUE wymaganie odstąpienia od zastosowania wyroku TK, co do odroczenia utraty mocy obowiązującej przepisu ustawy, łączyło się z odstąpieniem od zastosowania przepisu Konstytucji RP. Z perspektywy prawa unijnego nie było to nowością, ale potwierdzeniem szerokiego zakresu zasady pierwszeństwa prawa unijnego (wówczas wspólnotowego) w orzecznictwie TSUE, rozciągającego się na cały porządek prawny państw członkowskich ${ }^{18}$. Być może, przyczyną braku sprzeciwu wobec omawianego wyroku była okoliczność, w której sprawa nie budziła wątpliwości merytorycznych, a odstępstwo od stosowania prawa polskiego nie było dotkliwe. Zagadnienie relacji prawa unijnego do Konstytucji stało się - często w zniekształconej postaci - żywo dyskutowanym i kontrowersyjnym problemem wiele lat później ${ }^{19}$.

\section{Prowadzenie działalności hazardowej}

Wojewódzki Sąd Administracyjny w Gdańsku wydał w 2010 r. trzy postanowienia o skierowaniu pytań prejudycjalnych do TSUE ${ }^{20}$. Dotyczyły one interpretacji dyrektywy ustanawiającej procedurę notyfikacji w dziedzinie norm i przepisów technicznych ${ }^{21}$. Ujmując rzecz w skrócie: chodziło o to,

17 Wyroki TSUE: z 9 marca 1978 r., 106/77, Amministrazione delle Finanze dello Stato przeciwko Simmenthal SpA, ECLI:EU:C:1978:49; z 22 czerwca 2010 r. C-188/10, Melki i Abdeli, ECLI:EU:C:2010:363; z 15 stycznia 2013 r., C-416/10, Križan,ECLI:EU:C:2013:8.

18 Wyrok TSUE z 17 grudnia 1970 r. 11/70, Internationale Handelsgesellscha$\mathrm{ft} \mathrm{mbH}$ przeciwko Einfuhr- und Vorratsstelle für Getreide und Futtermittel, ECLI:EU:C:1970:114.

19 Wyrok TSUE z 2 marca 2021 r., C-824/18, A.B. przeciwko Krajowej Radzie Sądownictwa, powołany wyżej w przypisie 10.

20 Postanowienia WSA III SA/Gd 261/10, II SA/Gd 262/10, II SA/Gd 262/10.

21 Dyrektywa Parlamentu Europejskiego i Rady z 22 czerwca 1998 r., Dz. U. L 204, s. 37, ze zmianami. Akt ten został zastąpiony przez dyrektywę 2015/1535 Parlamentu Europejskiego i Rady z września 2015 r., ustanawiającą procedurę udzielania informacji w dziedzinie przepisów technicznych oraz zasad dotyczących usług społeczeństwa informacyjnego, Dz. Urz. UE, L 241/1. 
czy w świetle prawa unijnego występował obowiązek notyfikowania Komisji Europejskiej przepisów ustawy z dnia 19 listopada 2009 r. o grach hazardowych ${ }^{22}$ przed jej wejściem w życie. Istnienie takiego obowiązku było uzależnione od uznania niektórych przepisów ustawy za „przepisy techniczne” w rozumieniu prawa unijnego (dawniej wspólnotowego). Polska nie dokonała notyfikacji omawianych przepisów. Pytania skierowane przez WSA miały istotne znaczenie, ponieważ w świetle orzecznictwa TSUE nienotyfikowane przepisy krajowe będące przepisami technicznymi nie mogą wywierać skutków prawnych wobec jednostek, a w szczególności nie mogą być podstawą do nakładania na nich $\operatorname{kar}^{23}$.

Przepisy ustawowe, których charakter był zdaniem WSA niejasny $\mathrm{w}$ świetle prawa unijnego, wprowadzały daleko posunięte ograniczenia w prowadzeniu działalności gospodarczej w dziedzinie hazardu. Ograniczenia polegały na wprowadzeniu licznych zakazów dla organów właściwych $\mathrm{w}$ sprawach udzielania zezwoleń na prowadzenie omawianej działalności. Były to: zakaz zmiany udzielonych wcześniej zezwoleń na działalność w zakresie gier na automatach o niskich wygranych dotyczących miejsca urządzania gry, ponadto zakaz przedłużania czasu, na jaki zezwolenia zostały wydane, a także zakaz wydawania nowych zezwoleń na taką działalność. Prowadzenie działalności przez przedsiębiorców wbrew wymienionym zakazom było zagrożone wysokimi karami administracyjnymi i karami grzywny.

TSUE połączył trzy odesłania prejudycjalne do wspólnego rozpoznania i wydał wyrok ${ }^{24}$, którego teza brzmiała: Art. 1 pkt 11 dyrektywy o przepisach technicznych należy interpretować $w$ ten sposób, że przepisy tego rodzaju, jak polskie przepisy stanowia potencjalnie "przepisy techniczne” $w$ rozumieniu tego przepisu, w zwiazku z czym ich projekt powinien zostać przekazany Komisji w wypadku ustalenia, iz przepisy te wprowadzaja warunki mogace mieć istotny wpływ na właściwości lub sprzedaż produktów. Dokonanie tego ustalenia należy do sadu krajowego.

Przytoczony wyrok TSUE był żywo dyskutowany w praktyce stosowania prawa, i w polskiej literaturze oraz różnie rozumiany. Trzeba przyznać, że wyrok ten mógł budzić konfuzję przy nie dość dokładnym odczytaniu całego uzasadnienia. Przytoczona wyżej teza o „potencjalnym” charakterze przepisów polskiej ustawy jako przepisów technicznych była bowiem konfrontowana przez komentatorów ze sformułowaniami zawartymi w uzasadnieniu, w których była mowa o przepisach technicznych, ale bez

22 Dz. U. Nr 201, poz. 1540 ze zmianami.

23 Por. wszechstronne omówienie problematyki notyfikacji przepisów technicznych w pracy zbiorowej, M. Taborowski (red.), Skutki braku notyfikacji przepisów technicznych ustawy o grach losowych dla wymiaru sprawiedliwości Rzeczypospolitej Polskiej, Warszawa 2016.

24 Wyrok TSUE z 19 czerwca 2012 r., C-213/11, C-214/11 i C-217/11, Fortuna sp. z o.o. i in. przeciwko Dyrektorowi Izby Celnej w Gdyni, ECLI:EU:C:2012:495. 
przytoczonego przymiotnika. Ponadto wyrok wymagał od sądów krajowych oceny „istotnego wpływu” przepisów ustawowych.

Nie ma potrzeby wracania w tym miejscu do kontrowersji na tle interpretacji omawianego wyroku ${ }^{25}$. Wystarczy jedynie zauważyć, że postanowienia a potem wyroki WSA w Gdańsku w sprawach hazardowych i wyrok TSUE w sprawie Fortuna, zapoczątkowały „sagę hazardową”, na którą składały się także: powołany wyrok TK, liczne decyzje organów administracyjnych, wyroki sądów administracyjnych (WSA, NSA) i sądów powszechnych (karnych i cywilnych) oraz SN ${ }^{26}$. Niewątpliwie efektem wspomnianych orzeczeń, poza ich poważnymi skutkami ekonomicznymi i społecznymi, było ożywienie dyskusji na temat sposobów wykładni prawa unijnego oraz problemów stosowania prawa polskiego w kontekście prawa unijnego.

\section{Kontrola sądowa decyzji w sprawach wiz}

Na uwage zasługują dwa odesłania prejudycjalne NSA z 2016 i 2019 r. Problemem, o rozstrzygnięcie którego zwrócił się sąd, było to, czy w świetle prawa unijnego, łącznie z Kartą Praw Podstawowych, wymagana jest kontrola sądowa decyzji administracyjnych wydawanych przez konsulów w sprawach wizowych.

Inspiracją dla pierwszego postanowienia odsyłającego NSA ${ }^{27}$ była odmowa wydania przez konsula tzw. wizy Schengen obywatelowi państwa trzeciego, który zamierzał odwiedzić w Polsce żonę i dziecko - obywateli polskich. Na takie decyzje nie przysługiwała skarga do sądu administracyjnego (art. 5 pkt 4 ustawy Prawo o postępowaniu przed sądami administracyjnymi ${ }^{28}$, wobec czego WSA w Warszawie odrzucił wniesioną do niego skargę. Rozpoznając skargę kasacyjną NSA wystąpił do TSUE z pytaniem prejudycjalnym. Dotyczyło ono tego, czy przepisy wspólnotowego kodeksu wizowego, w związku z Kartą Praw Podstawowych należy rozumieć w ten sposób, że nakładają na państwo członkowskie obowiązek zagwarantowania środka zaskarżenia (odwołania) do sądu.

Trybunał Sprawiedliwości odpowiedział na to pytanie ${ }^{29}$, stwierdzając że: [a]rt. 32 ust. 3 rozporządzenia ustanawiającego Wspólnotowy Kodeks Wizowy, w świetle art. 47 Karty Praw Podstawowych UE należy interpretować $w$ ten sposób, że nakłada on na państwa członkowskie obowiązek

25 Interpretacja tego wyroku przez autora niniejszego artykułu została przedstawiona w zdaniu odrębnym do wyroku TK z 11 marca 2015 r., P 4/14, pkt 5.

26 Por. M. Taborowski (red.), Skutki braku notyfikacji..., passim.

27 Postanowienie NSA z dnia 28 czerwca 2016 r. II OSK 1346/16.

28 Ustawa z dnia 30 sierpnia 2002 r., Dz. U., Nr 153, poz. 1270 ze zmianami. Dalej cytowana jako: p.p.s.a.

29 Wyrok TSUE z dnia 13 grudnia 2017 r., C-403/16, El Hassani przeciwko Ministrowi Spraw Zagranicznych, ECLI:EU:C:2017:960. 
ustanowienia procedury odwoławczej od decyzji o odmowie wydania wizy, której szczegółowe zasady należa do porzadku prawnego każdego państwa członkowskiego, przy poszanowaniu zasad równoważności i skuteczności. Procedura ta musi gwarantować na pewnym etapie postępowania środek odwoławczy do sadu.

Po uzyskaniu powyższej odpowiedzi, NSA wydał postanowienie, w którym uchylił postanowienie WSA o odrzuceniu skargi ${ }^{30}$. Zdaniem NSA, biorąc pod uwagę wykładnię przepisów prawa Unii dokonaną przez TSUE, należy stwierdzić, że art. 5 pkt 4 p.p.s.a. jest niezgodny z art. 32 ust. 3 kodeksu wizowego w związku $\mathrm{z}$ art. 47 akapit pierwszy Karty praw podstawowych UE. Ze względu na wyrok Trybunału w rozpoznawanej sprawie i zasadę pierwszeństwa prawa unijnego, należało odmówić zastosowania powołanego przepisu ustawy, wyłączającego dopuszczalność skargi do sądu. Brak było bowiem podstaw do odrzucenia skargi.

Jak wynika z powyższych rozważań, postanowienie NSA i wyrok TSUE dotyczyły doniosłej kwestii zakresu ochrony sądowej praw jednostek przysługujących im w świetle prawa unijnego. Do wzrastających wymagań w tej materii przyczyniło się niewątpliwie nadanie mocy wiążącej Karcie Praw Podstawowych, a zwłaszcza jej art. 47, jakkolwiek omawiana tendencja do przyznawania ochrony sądowej była widoczna już wcześniej ${ }^{31}$. Wymagania wynikające $\mathrm{z}$ prawa unijnego $\mathrm{w}$ kształcie nadanym przez orzecznictwo TSUE wpływają na prawo państw członkowskich i niekiedy wymuszają wprowadzanie $\mathrm{w}$ nim zmian. W następstwie omawianego wyroku TSUE, została dokonana nowelizacja p.p.s.a. Dodany został art. 5 pkt 4a/, który poddał decyzje dotyczące wiz Schengen kontroli sądów administracyjnych.

Omówione wyżej rozstrzygnięcie skłoniło NSA do skierowania do TSUE kolejnego pytania prejudycjalnego $\mathrm{w}$ innej sprawie ${ }^{32}$. Tym razem wniosek o wykładnię prawa unijnego dotyczył wymagań proceduralnych w razie odmowy wydania innego rodzaju wiz: długoterminowych, wydawanych przez konsula na podstawie prawa polskiego, a nie wiz Schengen.

W rozpoznawanej sprawie, skarżący obywatel państwa trzeciego wystąpił do konsula $\mathrm{z}$ wnioskiem o wydanie krajowej wizy długoterminowej w celu podjęcia w Polsce studiów drugiego stopnia. Na decyzję odmowną nie przysługiwała w świetle p.p.s.a. skarga do sądu administracyjnego, wobec czego WSA wydał postanowienie o odrzuceniu skargi.

Wątpliwość NSA, rozpoznającego skargę kasacyjną, dotyczyła tego, czy osoba, której odmówiono wizy długoterminowej powinna mieć zapewnione prawo do skutecznego środka prawnego przed sądem na podstawie

30 Postanowienie NSA z dnia 19 lutego 2018 r., II OSK 1346/16.

31 Por. omówienie pierwszych wyroków statuujących ochronę sądową uprawnień jednostek wywodzonych z prawa unijnego (wspólnotowego), S. Biernat., Zasada efektywności prawa wspólnotowego w orzecznictwie Europejskiego Trybunału Sprawiedliwości [w:] Studia z prawa Unii Europejskiej, S. Biernat (red.), Kraków 2000, s. 54 i n.

32 Postanowienie NSA z dnia 4 listopada 2019, II OSK 2470/19. 
art. $47 \mathrm{KPP}$, ponieważ nie będzie mogła korzystać z prawa do swobodnego przemieszczania się po terytorium innych państw członkowskich wynikającego $\mathrm{z}$ art. 21 ust. 1 Konwencji wykonawczej do Układu z Schengen.

Odpowiedź TSUE została udzielona niejako w dwóch krokach ${ }^{33}$. Najpierw TSUE stwierdził, że art. 21 ust. 2 a Konwencji wykonawczej do Układu $z$ Schengen należy interpretować $w$ ten sposób, że nie znajduje on zastosowania do obywatela państwa trzeciego, któremu odmówiono wydania wizy dtugoterminowej.

Stwierdzenie to mogło oznaczać, że przedstawione zagadnienie znajduje się poza zasięgiem prawa unijnego. Ale TSUE się do tego nie ograniczył. Przypomniał, że nie jest związany pytaniami sądu krajowego i może udzielić sądowi odsyłającemu pomocy do wydania końcowego orzeczenia. Wobec tego orzekł, że prawo Unii, w szczególności art. 34 ust. 5 dyrektywy z 2016 r. w sprawie warunków wjazdu i pobytu obywateli państw trzecich $w$ celu prowadzenia badań naukowych, odbycia studiów, [...] $w$ świetle art. 47 Karty praw podstawowych UE, należy interpretować $w$ ten sposób, że nakłada ono na państwa członkowskie obowiazek ustanowienia procedury odwoławczej od decyzji o odmowie wydania wizy w celu odbycia studiów, w rozumieniu tej dyrektywy, której szczegółowe zasady należa do porzadku prawnego każdego państwa członkowskiego, przy poszanowaniu zasad równoważności i skuteczności, przy czym procedura ta musi gwarantować na pewnym etapie środek prawny przed sądem. Do sądu odsyłającego należy zbadanie, czy wniosek o wydanie wizy długoterminowej $w$ celu odbycia studiów rozpatrywany $w$ postępowaniu głównym jest objęty zakresem stosowania tej dyrektywy.

Z powyższych stwierdzeń wynika, że chociaż samo wydawanie wiz długoterminowych nie mieści się $\mathrm{w}$ zakresie prawa unijnego, to jednak okoliczności danej sprawy, a zwłaszcza cel przyjazdu obywatela państwa trzeciego ubiegającego się o wizę, mogą wykazywać związek z prawem unijnym. W omawianym przypadku związek ten może wynikać z treści dyrektywy unijnej ${ }^{34}$. Ustalenie, czy taka sytuacja rzeczywiście występuje, należy do sądu krajowego. Jeśli prawo unijne znajdowałoby zastosowanie, aktualne stawałyby się wymagania dotyczące zapewnienia sądowej ochrony praw jednostek.

Po otrzymaniu od TSUE odpowiedzi, NSA podjął zawieszone postępowanie i uchylił postanowienie WSA o odrzuceniu skargi ${ }^{35}$. Sąd przypomniał, że prawo UE stanowi część krajowego porządku prawnego. W przypadku

33 Wyrok TSUE z dnia 10 marca 2021 r., C-949/19, M.A. przeciwko Konsulowi Rzeczypospolitej Polskiej w N., ECLI:EU:C:2021:186.

34 Dyrektywa Parlamentu Europejskiego i Rady (UE) 2016/801 z dnia 11 maja 2016 r. w sprawie warunków wjazdu i pobytu obywateli państw trzecich w celu prowadzenia badań naukowych, odbycia studiów, szkoleń, udziału w wolontariacie, programach wymiany młodzieży szkolnej lub projektach edukacyjnych oraz podjęcia pracy w charakterze au pair, Dz. Urz. L 132/21.

35 Postanowienie NSA z dnia 13 kwietnia 2021 r., II OSK 2470/19 (2). 
kolizji normy unijnej i normy krajowej regulujących ten sam przedmiot, prawo Unii ma pierwszeństwo $\mathrm{w}$ stosowaniu przed normami krajowymi; wynika to z art. 91 ust. 3 Konstytucji RP. Polska - tak jak pozostałe państwa członkowskie - ma obowiązek stosowania prawa Unii, a także zapewnienia mu pełnej efektywności. Odrzucenie wniesionej skargi z przyczyny wskazanej przez sąd pierwszej instancji było przedwczesne, ponieważ w uzasadnieniu zaskarżonego postanowienia brak jest oceny, czy wniosek skarżącego o wydanie wizy długoterminowej w celu odbycia studiów jest objęty zakresem stosowania powołanej dyrektywy unijnej. Ze stwierdzeniem właściwości sądu administracyjnego do rozpoznania wniesionej skargi będzie wiązał się obowiązek jej merytorycznego rozpoznania przez WSA. Na uwagę zasługuje okoliczność, że NSA zastosował prawo unijne odstępując od p.p.s.a., bez czekania na ewentualną zmianę tej ustawy.

Omawiane tu drugie odesłanie prejudycjalne NSA dotyczące wiz i wyrok TSUE, są przejawem szerokiego interpretowania przepisów wyznaczających zakres zastosowania prawa unijnego, i tym samym będącego tego konsekwencją wymagania zapewnienia sądowej ochrony praw jednostek. Ponadto, postanowienie NSA wydane po otrzymaniu odpowiedzi TSUE jest zasługującym na aprobatę przykładem zastosowania zasady pierwszeństwa prawa unijnego nad ustawami, sformułowanej w art. 91 ust. 3 Konstytucji. Wynikiem oparcia się na zasadzie pierwszeństwa prawa unijnego przez sąd administracyjny, może być bowiem odmowa zastosowania przepisu p.p.s.a., wyłączającego dopuszczalność wnoszenia skarg na decyzje w sprawie wiz i dopuszczenie kontroli sądowej, jeśli okoliczności sprawy będą się mieścić w zakresie zastosowania prawa UE; w tym przypadku dyrektywy. Skarga będzie dopuszczalna z mocy prawa unijnego, nawet jeśli to nie wynika z przepisów ustawy ${ }^{36}$.

\section{Transkrypcja zagranicznego aktu urodzenia}

Wojewódzki Sąd Administracyjny w Krakowie wystąpił w 2020 r. do TSUE z pytaniem prejudycjalnym dotyczącym wykładni przepisów dotyczących swobody przemieszczania się obywateli Unii ${ }^{37}$. Zagadnienie to zostało przedstawione w kontekście kontrowersyjnego w Polsce zagadnienia transkrypcji niektórych zagranicznych aktów urodzenia.

36 Jest to rozwiązanie oparte na wyroku TSUE z 9.03.1978 r., 106/77, Amministrazione delle Finanze dello Stato przeciwko Simmenthal SpA, ECLI:EU:C:1978:49, powołanym w przypisie 17.

37 Postanowienie WSA z 9 grudnia 2020, III SA/Kr 1217/19. Tekstu postanowienia nie ma na oficjalnej stronie orzeczeń sądów administracyjnych, ale jest dostępny na stronie Rzecznika Praw Obywatelskich:

https://bip.brpo.gov.pl/sites/default/files/Postanowienie_pytanie_\%20prejudycjalne_ 9.12.2020.pdf 
Odesłanie prejudycjalne zostało skierowane w sprawie ze skargi Rzecznika Praw Obywatelskich do WSA na decyzję kierownika Urzędu Stanu Cywilnego, który odmówił transkrypcji aktu urodzenia sporządzonego w Hiszpanii, w którym jako rodzice dziecka zostały wpisane dwie kobiety. Jako uzasadnienie odmowy została podana sprzeczność aktu z podstawowymi zasadami porządku prawnego RP. W rezultacie, dziecko nie miało żadnego dokumentu tożsamości.

W toku rozpoznawania skargi na decyzję kierownika USC, WSA skierował do TSUE następujące pytanie prejudycjalne: czy art. 21 ust. $1 \mathrm{w} z w$. $z$ art. 20 ust. 2 lit. a TFUE $w z w . z$ art. 7 , art. 21 ust. 1 i art. 24 ust. 2 Karty praw podstawowych UE należy rozumieć $w$ ten sposób, że stoi on na przeszkodzie tego by organy państwa członkowskiego, którego obywatelstwo posiada małoletni, odmówity mu transkrypcji jego aktu urodzenia wydanego przez inne państwo członkowskie, niezbędnej do uzyskania dokumentu tożsamości państwa członkowskiego, którego obywatelstwo posiada, z tego powodu, $\dot{z}$ e prawo krajowe tego państwa nie przewiduje rodzicielstwa par jednopłciowych, a w akcie tym jako rodziców wskazano osoby tej samej płci.

Warto przypomnieć, że transkrypcja polega na wiernym i literalnym przeniesieniu treści obcego dokumentu do polskiego rejestru stanu cywilnego, zarówno pod względem językowym, jak i formalnie, bez żadnej ingerencji $w$ pisownię imion i nazwisk osób wskazanych $w$ zagranicznym dokumencie $e^{38}$.

Należy zauważyć, że zagadnienie zagranicznych aktów urodzenia z wpisanymi rodzicami tej samej płci występuje w Polsce już od pewnego czasu i wywołuje wątpliwości w praktyce administracyjnej i sądowoadministacyjnej. W celu ujednolicenia orzecznictwa, w 2019 r. została podjęta uchwała składu 7 sędziów NSA ${ }^{39}$, której teza brzmi: Przepis art. 104 ust. 5 $i$ art. 107 pkt 3 Prawo o aktach stanu cywilnego $z 2014$ r. $w$ zwiazku $z$ art. 7 ustawy z 2011 r. Prawo prywatne międzynarodowe nie dopuszcza transkrypcji zagranicznego aktu urodzenia dziecka, w którym jako rodzice wpisane sa osoby tej samej plci.

W tym stanie rzeczy, odesłanie prejudycjalne WSA w Krakowie zmierza $\mathrm{w}$ istocie do podważenia tej uchwały poprzez poddanie jej treści testowi zgodności z prawem unijnym.

Trzeba zauważyć, że prawo o aktach stanu cywilnego (p.a.s.c.) jest dziedziną, która nadal jest przedmiotem unormowań prawa krajowego. Normy p.a.s.c. mogą być jednak poddane ocenie TSUE wówczas, jeśli pozostają w związku z normami prawa unijnego. Tak jest właśnie w omawianej sprawie; pytanie WSA dotyczy wpływu polskich przepisów wprowadzających

38 Art. 103 ust. 2 ustawy z dnia 28 listopada 2014 r. Prawo o aktach stanu cywilnego, Dz. U. 2014 poz. 1741 ze zmianami.

39 Uchwała składu 7 sędziów NSA z dnia 2 grudnia 2019 r., II OPS 1/19. Por. M. Wojewoda, Zagraniczne rodzicielstwo osób jednej płci a rejestracja stanu cywilnego w Polsce - glosa do uchwały NSA (7) z 2.12.2019 r., II OPS 1/19, „Europejski Przegląd Sądowy" 2020, nr 8, s. 30 i n. 
ograniczenia transkrypcji zagranicznych aktów stanu cywilnego na możliwość korzystania z prawa do przemieszczania się obywateli Unii (art. 21 TFUE).

WSA argumentował, że przepisy polskiego prawa nie zapewniają dziecku, które jest obywatelem polskim i tym samym obywatelem Unii, prawa do swobodnego przemieszczania się po terytorium Unii. Jest tak dlatego, że wymagane dokumenty (paszport lub dowód osobisty) nie mogą zostać wydane, gdy rodzicami wpisanymi do aktu urodzenia dziecka są dwie kobiety. Kobiety te, zgodnie z prawem właściwym dla jednej z nich (obywatelki Irlandii), zawarły związek małżeński. Dokonanie transkrypcji hiszpańskiego aktu urodzenia pozwoli, zdaniem WSA, na wydanie dziecku dokumentu tożsamości. Umożliwi to przemieszczanie się między granicami państw członkowskich oraz zapewni ochronę życia prywatnego i rodzinnego. Stosownie do tego rozumowania, wyrok TSUE dokonujący wykładni prawa UE, w świetle której polskie prawo dotyczące transkrypcji aktów stanu cywilnego jest niezgodne z prawem unijnym, pociągałby za sobą konieczność odmowy zastosowania prawa polskiego, stosownie do zasady pierwszeństwa prawa unijnego. W omawianej sytuacji, oznaczałoby to zakaz odmowy transkrypcji zagranicznego aktu urodzenia, w którym wpisani byliby rodzice tej samej płci.

Należy jednak zaznaczyć, że stanowisko WSA opiera się na jednej z możliwości interpretacyjnych, ale nie jedynej. Inna możliwość wynika z wspomnianej wyżej uchwały 7 sędziów NSA z 2019 r. Został tam wyrażony pogląd, że wydanie dokumentu tożsamości, czy nadanie numeru PESEL, powinno być oderwane od transkrypcji aktu stanu cywilnego.

W uzasadnieniu tej uchwały, NSA stwierdził mianowicie, że: Prawidłowa wykładnia art. 104 ust. 5 p.a.s.c. nie może prowadzić do uzależnienia uzyskania przez obywatela polskiego dowodu tożsamości albo numeru PESEL od dokonania przez organ transkrypcji, która nie jest możliwa tylko $z$ tego powodu, że w zagranicznym akcie urodzenia dziecka podano zamiast danych ojca dane kobiety, która pozostaje w nieznanym polskiemu prawu zwiazku partnerskim $z$ matka dziecka będaca obywatelka polską. NSA odniósł się również do konsekwencji braku transkrypcji aktu urodzenia dla korzystania z praw obywateli Unii: Wynikajace $z$ TFUE prawo do swobodnego przemieszczania się $w$ ramach strefy Schengen nie jest uzależnione od posiadania transkrybowanego aktu urodzenia, ale od posiadania dokumentu tożsamości, które potwierdza obywatelstwo jednego z państw członkowskich Unii Europejskiej (...) Sprawa dotyczaca odmowy wydania dokumentów, na podstawie których dziecko skarżącej będzie mogło swobodnie przemieszczać się na terytorium Unii Europejskiej to odrębna sprawa administracyjna.

Innymi słowy, NSA rozróżnił dwa postępowania administracyjne: jedno w sprawie transkrypcji aktu urodzenia a drugie w sprawie wydawania dokumentów tożsamości, niezależnie od dokonania transkrypcji. Zasygnalizował też, że decyzje o odmowie wydania dokumentów tożsamości będą 
również podlegać kontroli sądów administracyjnych. Wykładnia dokonana przez NSA w omawianej uchwale składu 7 sędziów, nie jest jednak przyjmowana $\mathrm{w}$ praktyce funkcjonowania właściwych organów administracyjnych, o czym świadczy m.in. także omawiana sprawa ${ }^{40}$.

$\mathrm{W}$ sprawie tej nie został jeszcze wydany wyrok TSUE. Jest wysoce prawdopodobne, że wykładnia prawa dotycząca obywatelstwa unijnego doprowadzi Trybunał do wniosku o niezgodności z prawem unijnym prawa polskiego i praktyki, które uniemożliwiają korzystanie z prawa przemieszczania się obywateli Unii w wyniku przeszkód w wydaniu dziecku dokumentu tożsamości. Nie wiadomo natomiast, czy TSUE wskaże na niezgodność z prawem unijnym postępowania w sprawie transkrypcji zagranicznego aktu urodzenia, jak sugeruje sąd odsyłający, czy sformułuje swoje tezy szerzej, bez przesądzania, że wydanie polskiego dowodu tożsamości dziecka jest związane $\mathrm{z}$ transkrypcją aktu urodzenia. W każdym razie wydaje się, że po wydaniu wyroku TSUE, niezbędna okaże się zmiana polskiego prawa. Nie wystarczy raczej sama zmiana wykładni czy praktyk administracyjnych. Interesujące jest również, czy ocena w świetle prawa UE zostanie przeprowadzona w kontekście prawa przemieszczania się, czy szerzej - w kontekście dobra dziecka, ochrony życia rodzinnego i zakazu dyskryminacji.

Omawiana sprawa jest znamienna $\mathrm{z}$ wielu względów. Pokazuje oddziaływanie prawa UE na dziedziny zasadniczo objęte tylko prawem krajowym. Przede wszystkim, dotyczy zagadnień wrażliwych, będących wynikiem przemian obyczajowych, w których państwa członkowskie starają się zachować swobodę regulacyjną prawa krajowego, bez wpływu prawa unijnego. Okazuje się to trudne wobec konieczności ochrony praw i wolności gwarantowanych przez prawo UE, w tym zwłaszcza prawa przemieszczania się na terytorium Unii i zakazu dyskryminacji. Wpływ prawa unijnego na prawo krajowe staje się coraz bardziej odczuwalny.

\section{Instalowanie farm wiatrowych}

Interesujące problemy na pograniczu prawa polskiego i unijnego pojawiły się w sprawie wynikającej z odesłania prejudycjalnego WSA w Kielcach z $2017 \mathrm{r}^{41}$. Sąd ten rozpoznawał skargę na odmowę wydania decyzji administracyjnej o środowiskowych uwarunkowaniach realizacji przedsięwzięcia: budowa i eksploatacja farmy wiatrowej.

40 Świadczy o tym również wystąpienie Rzecznika Praw Obywatelskich do Ministra Spraw Wewnętrznych i Administracji z dnia 1 marca 2021 r., https://bip.brpo.gov. $\mathrm{pl} / \mathrm{pl} /$ content/rpo-polskie-dokumenty-i-dla-dzieci-z-zagranicznych-zwiazkow-osob-jednej-plci.

41 Postanowienie WSA z dnia 12 października 2017 r. w sprawie II SA/Ke 337/17. 
W toku postępowania, WSA powziął wątpliwości, co do zgodności $\mathrm{z}$ prawem unijnym ustawy o inwestycjach $\mathrm{w}$ zakresie elektrowni wiatrowych ${ }^{42}$. W ustawie zostały wprowadzone surowe wymagania, co do odległości usytuowania wiatraków od zabudowań mieszkalnych. Spowodowało to poważne ograniczenia możliwości zakładania farm wiatrowych.

W odesłaniu prejudycjalnym WSA sformułował pytania dotyczące interpretacji prawa unijnego. Ogólnie rzecz ujmując, dotyczyły one tego, czy przed wydaniem omawianych przepisów ustawowych Polska miała obowiązek notyfikowania ich Komisji Europejskiej. Podstawą tego obowiązku miały być dwie dyrektywy unijne. Ponadto WSA zapytał, czy przewidziane w polskiej ustawie surowe wymagania, co do sytuowania wiatraków są zgodne z kolejną dyrektywą unijną o promowaniu energii odnawialnej.

Odpowiadając na te pytania, TSUE stwierdził, że zasadniczo nie było obowiązku notyfikacji omawianych przepisów ustawowych ${ }^{43}$. Nie występowała też niezgodność $\mathrm{z}$ dyrektywą $\mathrm{w}$ sprawie promowania odnawialnych źródeł energii. Jednak TSUE wskazał w wyroku na to, że w pewnych sytuacjach, rzecz się może przedstawiać inaczej. Zrelatywizował zatem swoje stanowisko w dwóch kwestiach. Tak więc, po pierwsze, przepis wprowadzający surowe wymagania dotyczące minimalnej odległości sytuowania farm wiatrowych nie wymaga notyfikacji, o ile jego ustanowienie nie skutkuje jedynie marginalnym użytkowaniem turbin wiatrowych. Po drugie, wymaganie zachowania minimalnej odległości jest zgodne z dyrektywą o promowaniu energii odnawialnej, jeśli jest to uregulowanie niezbędne i proporcjonalne w świetle wiążącego dane państwo członkowskie, obowiązkowego, krajowego celu ogólnego.

Istotne $\mathrm{w}$ kontekście omawianych tu zagadnień procedury prejudycjalnej, było to, że w odniesieniu do obu sytuacji, TSUE zastrzegł, iż sprawdzenie wskazanych okoliczności decydujących o ostatecznym rozstrzygnięciu, należy do sądu odsyłającego. Formuła taka występuje, jak wiadomo, bardzo często w wyrokach prejudycjalnych. Odzwierciedla ona charakterystyczny dla postępowania prejudycjalnego podział ról między TSUE a sądy krajowe $^{44}$.

42 Ustawa z dnia 20 maja 2016 r., Dz. U. 2016 poz. 961.

43 Wyrok TSUE z 28 maja 2020 r. C-727/17, Syndyk Masy Upadłości ECO-WIND Construction S.A. w upadłości przeciwko Samorządowemu Kolegium Odwoławczemu w Kielcach, ECLI:EU:C:2020:393.

44 Por. pkt 11 zaleceń TSUE dla sądów krajowych dotyczących składania wniosków o wydanie orzeczenia w trybie prejudycjalnym (2019/C 380/01), PL Dz. Urz. UE, C 380/1 z 8.11.2019: „(...) Orzekając w przedmiocie wykładni lub ważności prawa Unii, Trybunał stara się udzielić odpowiedzi użytecznej dla rozstrzygnięcia sporu w postępowaniu głównym, lecz to do sądu odsyłającego należy wyciągnięcie z niej konkretnych wniosków, w tym - w razie potrzeby - podjęcie decyzji o niezastosowaniu przepisu prawa krajowego uznanego za niezgodny z prawem Unii." https://eur-lex.europa .eu/legal-content/PL/TXT/PDF/?uri=OJ:JOC_2019_380_R_0001. 
Tak więc TSUE zobowiązał sąd odsyłający do uwzględnienia sformułowanych przez siebie zaleceń w wyroku kończącym sprawę. Pojawia się tu jednak istotny i trudny problem o charakterze ogólnym. Dotyczy on tego, czy i w jaki sposób sądy administracyjne mogą podołać obowiązkom ustalenia okoliczności istotnych dla oceny zgodności prawa krajowego z prawem Unii w danej sprawie. Dla zilustrowania pojawiających się trudności, warto przedstawić pokrótce postępowanie przed WSA, po otrzymaniu odpowiedzi od TSUE. Należy jednak podkreślić, że problem nie ogranicza się oczywiście do analizowanego tu przypadku.

Rozpoznając sprawę, po podjęciu zawieszonego postępowania, WSA zwrócił się do Ministra Środowiska i do Ministra Klimatu o udzielenie odpowiedzi na kilka obszernych i szczegółowych pytań. Miały one dostarczyć materiału do sprawdzenia tego, co nakazał TSUE, tj. do ustalenia wpływu znowelizowanych przepisów ustawowych na produkcję energii wiatrowej i zachodzące w niej zmiany. Sąd otrzymał odpowiedzi od ministrów, które obszernie omówił w uzasadnieniu wyroku. Można było wnosić, że WSA zamierzał dokonać samodzielnie sprawdzenia okoliczności wskazanych przez TSUE.

$\mathrm{W}$ trakcie postępowania, pogląd $\mathrm{w}$ sprawie przedstawiła Prokuratoria Generalna. Stwierdziła w obszernym wywodzie, że polskie przepisy nie naruszają prawa unijnego. Zwróciła ponadto uwagę, że w polskim modelu sądownictwa administracyjnego, sądy nie dokonują ustaleń faktycznych, ponieważ należy to do organów administracyjnych. Można przypuszczać, że stanowisko Prokuratorii Generalnej wpłynęło na rozstrzygnięcie dokonane przez WSA. Sąd ten wydał wyrok, w którym uchylił decyzje organów obu instancji i zobowiązał organ administracyjny, który wydał zaskarżoną decyzję w pierwszej instancji do dokonania ustaleń, które wskazał TSUE ${ }^{45}$.

$\mathrm{Na}$ tle omawianej sprawy, należy zasygnalizować generalny problem: jaka jest relacja między występującymi w wyrokach prejudycjalnych wezwaniami dla sądów krajowych do dokonania określonych ustaleń lub ocen dotyczących okoliczności prawnych lub faktycznych sprawy a polskim modelem sądownictwa administracyjnego, określonym w art. 184 Konstytucji? Model ten charakteryzuje się tym, że sądy sprawują kontrolę działalności administracji publicznej, ale nie zastępują organów administracyjnych. Badając zgodność z prawem decyzji administracyjnych ${ }^{46}$, sądy orzekają na podstawie akt sprawy (art. $133 \$ 1$ p.p.s.a.) i nie dokonują ustaleń faktycznych ani zasadniczo nie przeprowadzają postępowania dowodowego. Jedynie na podstawie art. $106 \S 3$ p.p.s.a. sąd może z urzędu lub na wniosek stron przeprowadzić dowody uzupełniające z dokumentów, jeżeli jest to

45 Wyrok WSA z 27 października 2020, II SA/Ke 337/17.

46 Oczywiście zakres kontroli sprawowanej przez sądy administracyjne jest znacznie szerszy (art. 3 p.p.s.a.). 
niezbędne do wyjaśnienia istotnych wątpliwości i nie spowoduje nadmiernego przedłużenia postępowania $\mathrm{w}$ sprawie.

Powstaje zagadnienie, jak pogodzić zarysowane wyżej rozwiązania ustawowe z faktem, że TSUE wskazuje często w wyrokach prejudycjalnych okoliczności decydujące o zgodności lub niezgodności prawa krajowego z prawem unijnym, które to okoliczności mają ustalić, zbadać, czy ocenić sądy odsyłające (w tym sądy administracyjne). Rysuje się napięcie w związku z podziałem ról między organy administracyjne a sądy w kontekście wymagań wynikających z niektórych wyroków prejudycjalnych.

Pojawiają się dwie możliwości rozwiązania tego zagadnienia.

Pierwsza możliwość charakteryzuje się tym, że powierzenie w wyroku prejudycjalnym dokonania określonych ustaleń przez sądy administracyjne, należy rozumieć zgodnie z zasadą autonomii proceduralnej państw członkowskich jako zobowiązanie tych sądów do poczynienia ustaleń i przeprowadzenia ocen, o ile jest to dopuszczalne w świetle polskiego prawa. Jeśli ustalenie okoliczności relewantnych dla oceny zgodności lub niezgodności z prawem unijnym prawa polskiego wymaga przeprowadzenia postępowania dowodowego, wówczas niezbędne jest uchylenie zaskarżonej decyzji przez sąd i przekazanie sprawy do ponownego rozpatrzenia przez organ administracyjny. Rozstrzygnięcia organu administracyjnego (organów administracyjnych) będą podlegać kontroli sądów administracyjnych.

Druga możliwość polega natomiast na tym, że ustalenie okoliczności niezbędnych do oceny polskiego prawa w świetle prawa unijnego, mogłoby być także dokonywane bezpośrednio przez sąd administracyjny stosownie do wskazań zawartych w wyroku TSUE, bez konieczności przekazywania sprawy organowi administracyjnemu.

Pierwsze, zarysowane wyżej rozwiązanie, jest zgodne z polskim prawem o postępowaniu przed sądami administracyjnymi, ale $\mathrm{w}$ wielu sytuacjach może okazać się nieefektywne. Jego wadą jest przedłużenie postępowania. Przede wszystkim jednak, powstają wątpliwości, czy organy administracyjne są w stanie sprostać nałożonym na nie zadaniom, czyli dokonać wymaganych przez TSUE ustaleń i ocen. Przykładowo, w omawianej tu sprawie farm wiatrowych, to na burmistrza małego miasta jako organu administracyjnego pierwszej instancji i na SKO jako organu odwoławczego spadł ciężar ustalenia i oceny wpływu nowych przepisów ustawowych dotyczących sytuowania farm wiatrowych na zmiany w efektach polityki energetycznej prowadzonej w skali całego państwa.

Drugie rozwiązanie oznacza natomiast odstąpienie od ograniczeń wynikających z polskiego prawa w odniesieniu do obecnej roli sądów administracyjnych ${ }^{47}$. Polega to na przyznaniu sądom kompetencji do samodzielnego dokonywania ustaleń faktycznych i ocen prowadzących do końcowych

47 Por. szerzej o wpływie prawa unijnego na kognicję sądów administracyjnych, N. Półtorak, Ochrona uprawnień wynikających z prawa Unii Europejskiej w postępowaniach krajowych, Warszawa 2010, s. 306 i n. 
konkluzji w kwestii zgodności prawa polskiego z prawem unijnym. Zakłada to bardziej aktywną rolę sądów.

Rozważane tu koncepcje wykonania wskazań TSUE wiążą się częściowo $\mathrm{z}$ dyskutowanym $\mathrm{w}$ ostatnich latach zagadnieniem przyznania sądom administracyjnym kompetencji do merytorycznego załatwiania spraw $^{48}$. Elementem i efektem tej dyskusji była ustawa nowelizująca p.p.s.a. w 2015 r. $^{49}$. Obecnie, w ustawie tej znajduje się kilka przepisów, które można uznać za przejawy merytorycznego rozstrzygania spraw przez sądy administracyjne, wykraczające poza ich tradycyjną rolę kasacyjną ${ }^{50}$. Nie zmieniają one jednak zasadniczo roli tych sądów. W szczególności, pozostają w mocy wspomniane wyżej przepisy art. $106 \$ 3$ i art. $133 \$ 1$ p.p.s.a.

Rozważane tu przyznanie sądom administracyjnym uprawnień do dokonywania ustaleń i ocen wskazanych przez TSUE w wyrokach prejudycjalnych oznaczałoby ich wyjście poza obecną rolę. Niekoniecznie łączyłoby się to z przyznaniem im kompetencji do merytorycznego orzekania, ale $\mathrm{z}$ samodzielnym przeprowadzaniem dowodów $\mathrm{w}$ znacznie szerszym zakresie, niż wynika to $\mathrm{z}$ art. $106 \$ 3$, tak jak jest on obecnie interpretowany w praktyce sądowej.

Warto zwrócić uwagę na formułowane w najnowszej literaturze ogólne postulaty rozszerzenia kompetencji sądów administracyjnych do przeprowadzania postępowania dowodowego ${ }^{51}$. Należy się opowiedzieć za tym rozwiązaniem, w każdym razie w dziedzinach objętych prawem unijnym. Z zasady lojalności państw członkowskich wobec Unii (art. 4 ust. 3 TUE) oraz z konstrukcji procedury prejudycjalnej (art. 267 TFUE) można wyprowadzić obowiązek państw członkowskich zapewnienia skuteczności wyrokom prejudycjalnym. Niewątpliwie, tej skuteczności może sprzyjać dokonywanie ustaleń i ocen bezpośrednio przez sąd administracyjny, bez potrzeby zwracania się w każdym przypadku do organów administracyjnych. Oparcie się na zasadzie pierwszeństwa prawa UE może uzasadniać zmianę dotychczasowej wykładni powołanych przepisów p.p.s.a., albo nawet odstąpienie od stosowania tych przepisów, które wyłączają w większości przypadków przeprowadzanie postępowania dowodowego przed sądami administracyjnymi.

48 Por. przykładowo Z. Kmieciak, Merytoryczne orzekanie przez sądy administracyjne w świetle konstytucyjnej zasady podziału władz, „Przegląd Legislacyjny” 2015, nr 2, s. 9 i n.; W. Piątek, Nowe kompetencje do merytorycznego orzekania przez sądy administracyjne, „Państwo i Prawo” 2017, nr 1, s. 19 i n.; J. Chlebny, W. Piątek, Ewolucja ustrojowa i kompetencyjna sądownictwa administracyjnego, „Zeszyty Naukowe Sądownictwa Administracyjnego" 2021, nr 1-2, s. 23 i n.

49 Ustawa z 9 kwietnia 2015 r., Dz. U., poz. 658.

50 Z. Kmieciak, Merytoryczne orzekanie..., s. 12, wymienia w tym kontekście: art. $145 \mathrm{a}$, art. $146 \$ 2$, art.149 $\$ 1$ pkt 2 , art.149 $\$ 1$ b oraz art. $154 \$ 2$ oraz z zastrzeżeniem: art. $145 \$ 3$ p.p.s.a.

51 Por. obszerne i udokumentowane uwagi o dysfunkcjonalności obecnych rozwiązań prawnych, J. Chlebny, W. Piątek, Ewolucja ustrojowa..., s. 26 i n. 
Jest to tendencja widoczna już w prawie UE. Charakterystycznym przykładem zobowiązania sądów państw członkowskich do przeprowadzania pełnego postępowania dowodowego może być art. 31 dyrektywy 2004/38/ WE Parlamentu Europejskiego i Rady w sprawie prawa obywateli Unii i członków ich rodzin do swobodnego przemieszczania się i pobytu na terytorium państw członkowskich ${ }^{52}$. Przepis ten przyznaje obywatelom państw członkowskich ochronę sądową, w razie wprowadzenia wobec nich ograniczeń w prawie wjazdu i prawie pobytu w innym państwie członkowskim, uzasadnionych względami porządku publicznego, bezpieczeństwa publicznego lub zdrowia publicznego. Istotne jest przy tym to, że, stosownie do art. 31 ust. 3 przytoczonej dyrektywy, procedury odwoławcze umożliwiają zbadanie zgodności z prawem decyzji oraz faktów i okoliczności, na których opierały się proponowane środki ${ }^{33}$. Innym przykładem jest art. 46 ust. 3 dyrektywy Parlamentu Europejskiego i Rady 2013/32/UE z 2013 r. w sprawie wspólnych procedur udzielania i cofania ochrony międzynarodowej ${ }^{54}$. Stosownie do tego przepisu, państwa członkowskie zapewniają, aby skuteczny środek zaskarżenia zapewniał pełne rozpatrzenie ex nunc zarówno okoliczności faktycznych, jak i kwestii prawnych, w tym, w stosownych przypadkach, rozpatrzenie potrzeby zapewnienia ochrony międzynarodowej na mocy dyrektywy 2011/95/UE, co najmniej w postępowaniach odwoławczych przed sądem pierwszej instancji ${ }^{55}$. Obowiązek aktywności sądów administracyjnych $\mathrm{w}$ dziedzinach objętych prawem Unii, nawet wbrew prawu krajowemu został potwierdzony niedawno w orzecznictwie TSUE ${ }^{56}$.

Konkludując, byłoby korzystniej, gdyby ustalenia wymagane przez TSUE w sprawie farm wiatrowych zostały dokonane bezpośrednio przez WSA.

\section{Refleksja końcowa}

Omówione wyżej sprawy są bardzo różne, jeśli chodzi o ich przedmiot i problemy prawne, jakie na ich tle powstają. Wspólne jest dla nich to, że dzięki skierowaniu przez poszczególne sądy administracyjne pytań prejudycjalnych i uzyskaniu odpowiedzi na nie ze strony TSUE, udaje się rozwiać wątpliwości interpretacyjne wykraczające poza jednostkowe postępowania sądowoadministracyjne. To powinno skłaniać sądy administracyjne

52 Dyrektywa z dnia 29 kwietnia 2004 r., Dz. Urz. L 158/ 77.

53 Por. N. Półtorak, Ochrona uprawnień..., s. 314 i n.

54 Dyrektywa z dnia 26 czerwca 2013 r., Dz. Urz. L 180/60.

55 Por. J. Chlebny, Prawo o cudzoziemcach. Komentarz, Warszawa 2020, s. 886 i n.

56 Por. P. Iżycki, O merytorycznym orzekaniu sąów administracyjnych $w$ świetle standardu europejskiego - refleksje na gruncie wyroku Trybunału Sprawiedliwości z 29.07.2019 r., C-556/17, Alekszij Torubarov przeciwko Bevándorlásiés Menekültügyi Hivatal, „Europejski Przegląd Sądowy” 2020, nr 4, s. 36 i n. 
do coraz częstszego korzystania $\mathrm{z}$ dialogu $\mathrm{z}$ trybunałem luksemburskim. Tezy sformułowane przez TSUE w przedstawionych wyżej sprawach mają znaczenie dla polskiego prawa, stawiając przed nim niekiedy nowe wyzwania. Ponadto, niektóre tezy są istotne także dla rozwoju prawa unijnego, a omawiane wyroki już trafiły, albo mają szanse trafić do podręczników prawa europejskiego.

\section{Bibliografia}

Biernat S., Zasada efektywności prawa wspólnotowego w orzecznictwie Europejskiego Trybunatu Sprawiedliwości [w:] Studia z prawa Unii Europejskiej, S. Biernat (red.), Kraków 2000.

Biernat S., Łętowska E., Komentarz do oświadczenia sędziów Trybunału Konstytucyjnego w stanie spoczynku z 10 października 2021 r., http://konstytucyjny .pl/s-biernat-e-letowska-komentarz-do-oswiadczenia-sedziow-trybunalu -konstytucyjnego-w-stanie-spoczynku-z-10-pazdziernika-2021-r/.

Chlebny J., Prawo o cudzoziemcach. Komentarz, Warszawa 2020.

Chlebny J., Piątek W., Ewolucja ustrojowa i kompetencyjna sądownictwa administracyjnego, „Zeszyty Naukowe Sądownictwa Administracyjnego” 2021, nr 1-2.

Iżycki P., O merytorycznym orzekaniu sądów administracyjnych $w$ świetle standardu europejskiego - refleksje na gruncie wyroku Trybunału Sprawiedliwości z 29.07.2019 r., C-556/17, Alekszij Torubarov przeciwko Bevándorlásiés Menekültügyi Hivatal, „Europejski Przegląd Sądowy” 2020, nr 4.

Kmieciak Z., Merytoryczne orzekanie przez sądy administracyjne w świetle konstytucyjnej zasady podziału władz, „Przegląd Legislacyjny” 2015, nr 2.

Piątek W., Nowe kompetencje do merytorycznego orzekania przez sądy administracyjne, „Państwo i Prawo” 2017, nr 1.

Półtorak N., Ochrona uprawnień wynikających $z$ prawa Unii Europejskiej w postępowaniach krajowych, Warszawa 2010.

Taborowski M. (red.), Skutki braku notyfikacji przepisów technicznych ustawy o grach losowych dla wymiaru sprawiedliwości Rzeczypospolitej Polskiej, Warszawa 2016.

\section{Czego uczą pytania prejudycjalne sądów administracyjnych}

\section{Streszczenie}

Artykuł zawiera analizę kilku wybranych wyroków prejudycjalnych TSUE wydanych w odpowiedzi na odesłania polskich sądów administracyjnych. W wyrokach tych zostało poruszonych wiele zagadnień istotnych z punktu widzenia zarówno prawa UE, jak i prawa polskiego: pierwszeństwo prawa UE, zakres pojęcia "przepisów technicznych" w prawie UE, ochrona prawna adresatów decyzji odmownych w sprawach wiz, ograniczeń swobody przemieszczania się obywateli Unii po jej terytorium, a także zakresu uprawnień sądów administracyjnych do przeprowadzania postępowania dowodowego w celu wykonania wyroków prejudycjalnych TSUE.

Słowa kluczowe: sądy administracyjne, Trybunał Sprawiedliwości Unii Europejskiej, procedura prejudycjalna, pierwszeństwo prawa Unii Europejskiej 


\section{What do Preliminary References by Administrative Courts Teach Us?}

Abstract

The article analyses several preliminary rulings of the CJEU issued in response to references from Polish administrative courts. These rulings dealt with a number of issues relevant to both EU law and Polish law: the independence of the courts and the judges from the Member States, primacy of EU law, the scope of the term 'technical standards and regulations' in EU law, judicial appeal procedure against administrative decisions refusing visas, the limitations of the right of citizens of the Union to move and reside freely within the territory of the Member States, and the competence of administrative courts to conduct evidence proceedings in order to implement the preliminary rulings of the CJEU.

Keywords: administrative courts, the Court of Justice of the European Union, the preliminary ruling procedure, the primacy of European Union law 